\title{
RISK OF GROUNDWATER POLLUTION IN OPEN DUG WELLS IN THE PUNGUDUTIVU ISLAND OF THE JAFFNA PENINSULA, SRI LANKA
}

\author{
S. PATHMAJA ${ }^{1}$, H.A. DHARMAGUNAWARDHANE ${ }^{2}$, M. SENTHILNANTHANAN ${ }^{1}$, \\ T. MIKUNTHAN ${ }^{3}$, L.D. RAJASOORIYAR ${ }^{4 *}$ \\ ${ }^{1}$ Department of Chemistry, University of Jaffna, Sri Lanka \\ ${ }^{2}$ Department of Geology, University of Peradeniya, Sri Lanka \\ ${ }^{3}$ Department of Agricultural Engineering, University of Jaffna, Sri Lanka \\ ${ }^{4}$ Department of Geography, University of Jaffna, Sri Lanka \\ *Corresponding author e-mail: lorraine.rajasooriyar@gmail.com
}

(Received 26 $6^{\text {th }}$ August 2019; accepted $4^{\text {th }}$ October 2019)

\begin{abstract}
Un-protected open dug wells of shallow groundwater environments are subjected to high risk of chemical and microbial pollution in many parts of the world. The present study was initiated in Pungudutivu, one of the surrounding islands of the Jaffna Peninsula, Sri Lanka, because the island totally relies on its limited groundwater resources extracted from open dug wells to meet all its needs. The study assessed the risk of pollution within the limited fresh groundwater found in unconfined aquifer systems of Pungudutivu, where high risk of pollution was expected mainly from organic sources, derived from human and animal wastes and easy infiltration and runoff returns. The fresh groundwater pockets of Pungudutivu were however found to be with less serious contamination risks other than high $\mathrm{Fe}^{2+}$ and high faecal coliform counts. Low nitrate and phosphate concentrations with high COD and low BOD demonstrated less pollution from biodegradable organic sources in the midst of high oxidising potentials in the shallow dug wells as implied by the stability field of $\mathrm{Fe}(\mathrm{OH})_{3}$ on the Eh-pH diagram; the argument of high $\mathrm{Fe}^{2+}$ in groundwater however, wasn't supported by the said oxidation potential. High faecal coliform counts with high DO in groundwater probably indicated conditions implied by on site waste disposal in groundwater of Pungudutivu.
\end{abstract}

Keywords: Groundwater, Pollution, Risk, Pungudutivu, Jaffna Peninsula.

\section{INTRODUCTION}

Groundwater acts as a major source for drinking in many parts of the world, thus, the quality of groundwater is important in preventing hazards towards human health (Chapman, 1996). Ensuring safe drinking water found in shallow and deep groundwater sources is the prime challenge faced by the developing world in the present era including rural Sri Lanka. Tapping groundwater from shallow aquifers implies challenges towards water quality, especially when such wells are closer to settlements and related beneficiary communities (Lutterodt et al., 2018). In Sri Lanka, a majority of people extract groundwater for drinking from shallow dug wells (MENR, UNEP 2009). Monitoring and assessment of the chemical and microbial quality of water from hand-dug wells is therefore important in order to incorporate effective management strategies to improve the quality of water from the available sources and to bring them into optimum utilisation within communities that rely on them (Shivasorupy et al., 2012). 
Jaffna Peninsula, the northern most region of Sri Lanka (Fig.1.0) is well known for its fresh groundwater resources stored in Miocene limestone aquifers to meet drinking, domestic and livelihood needs of the area in the past couple of centuries in the absence of perennial surface water resources (Rajasooriyar et al., 2002). Though Jaffna aquifers meet the needs of drinking and domestic waters of the majority of beneficiary communities, pollution due to high nitrate concentrations and high numbers of faecal coliform was found in the recent past in the large diameter open dug wells that were with potential oxidising conditions, in the agricultural areas and the densely populated urban Jaffna, probably due to agricultural inputs and improper human waste disposal respectively (Mikunthan and De Silva, 2008; Rajendran et al., 2008; Joshua et al., 2013; Hidayathulla and Karunaratna, 2013; Jeevaratnam et al., 2018; Mahagamage et al., 2019). Adoption of effective management strategies incorporating public awareness and community participation were emphasised as prime requirements for managing shallow groundwaters and bringing them into optimum utilisation for feasible and economic management of the resource in Jaffna (Nesiah et al., 2005). In such context, monitoring and evaluation of the quality of shallow groundwaters and related risks of contamination was a prime requirement in Jaffna at the post war rehabilitation scenario because decisions are being taken on the development of infrastructures towards drinking water supplies and waste disposal in the Jaffna town and the surrounding islands involving high technologies and vast capital investments.

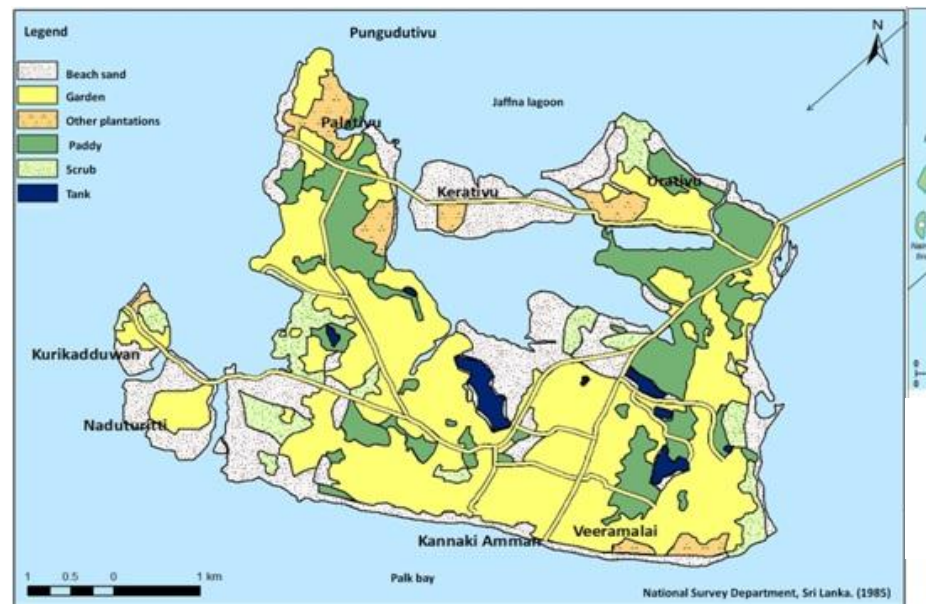

Such decisions however, required to be scientifically justifiable with respect to the extent of pollution in Jaffna groundwater and its impacts on human health. In order to meet this objective, Pungudutivu, a small island adjoining the Jaffna Peninsula (Fig. 1) was selected as a pilot study area to assess the risk of open source pollution in the rural Jaffna. The Pungudutivu is a flat landscape with an area of $28.9 \mathrm{~km}^{2}$ and maximum land surface elevation of $3.0 \mathrm{~m}$ above mean sea level (MSL). It is underlain by highly porous, fossiliferous limestone. Beach sand, yellow brown sand and lagoonal and estuarine deposits are the major unconsolidated formations found in this area (Cooray, 1984). Only a few pockets of freshwater exist in the unconfined aquifer systems of Pungudutivu to meet the drinking water needs of a few neighbouring households and this water is extracted from large diameter open dug wells (Pathmaja et al., 2016). Waste from small scaled livestock farming and fishing from existing livelihood as well as runoff returns into the dug wells during the rainy season were expected to pose high pollution risks from organic wastes due to the un-protective nature of dug wells.

Agricultural activities contributing towards groundwater pollution appeared to be minimal as cultivation in the long dry season was completely abandoned due to water scarcity (Pathmaja, 2016). Therefore, the unconsolidated formation of lagoon and estuarine deposits of the study area were considered as a contributing factor to pollution by organic matter. 
Assessing any threats on the quality of fresh groundwater available in the limited number of freshwater pockets of Pungudutivu Island, therefore, was considered important for identifying appropriate management strategies at local levels for the protection of fresh groundwater resources as well as to ensure drinking water qualities in the rural Jaffna District.

\section{MATERIALS AND METHODS}

The present study was carried out in the peak dry period (September, 2015) and the period followed by rains (March, 2016) as part of a major research project of this nature where detailed chemical and geophysical investigations were carried out for a period of one year beginning from March 2015. Thirty six dug well localities were monitored in Pungudutivu, for Electrical Conductivity, Temperature (HQ40d- Multi meter), DO (HQ30d- Flexi meter), pH, Eh (LPVpH meter) along with major cations $\left(\mathrm{Ca}^{2+}, \mathrm{Mg}^{2+}, \mathrm{Na}^{+}, \mathrm{K}^{+}\right.$, $\left.\mathrm{Fe}^{2+}\right)$ and anions $\left(\mathrm{HCO}_{3}{ }^{-}, \mathrm{CO}_{3}{ }^{2-}, \mathrm{Cl}^{-}, \mathrm{SO}_{4}{ }^{2-}, \mathrm{NO}_{3}{ }^{-}\right.$ , $\left.\mathrm{PO}_{4}{ }^{3-}\right)$ and a few minor ions, Biochemical Oxygen Demand (BOD), Chemical Oxygen Demand (COD) and Faecal coliforms. In addition, groundwater table depths were measured to assess the quality of groundwater and the risks of contamination in open dug wells. The micro-biological quality (total coliforms and E.coli) was monitored in 20 wells from public potable water sources, to ensure the drinking water quality in the study area in the absence of extensive studies on the impacts of groundwater quality.

Determination of chemical parameters were carried out by adopting the procedures described by the American Public Health Association (APHA, 1998); $\mathrm{Ca}^{2+}, \mathrm{Mg}^{2+}, \mathrm{HCO}_{3}{ }^{-}, \mathrm{CO}_{3}{ }^{2-}, \mathrm{Cl}^{-}$, and $\mathrm{SO}_{4}^{2-}$ by titrimetry, $\mathrm{Na}^{+}$by Atomic Absorption Spectrometer, $\mathrm{NO}_{3}{ }^{-}, \mathrm{PO}_{4}{ }^{3-}$ and $\mathrm{Fe}^{2+}$ by UV-Visible spectrophotometer (DR 1900) and $\mathrm{K}^{+}$by Flame photometer. BOD, COD and Faecal coliform were determined using standards of Australian Laboratory Services (ALS, 2013).

\section{RESULTS AND DISCUSSION}

Well waters of Pungudutivu are exposed to the atmosphere. The average well water temperature is $30.4^{\circ} \mathrm{C}$. $\mathrm{pH}$ of well waters shows more alkaline conditions in both seasons with a highest value of 9.34 (Table 1). Eh values are in the range of 79 to $279 \mathrm{mV}$ in the dry season and 110 to $315 \mathrm{mV}$ in the wet season. The negative correlation between $\mathrm{pH}$ and Eh values $\left(\mathrm{r}^{2}=\right.$ 0.98) of groundwater along with high Dissolved Oxygen of up to $21.19 \mathrm{mg} / \mathrm{L}$ (Fig. 2) exemplify oxidizing conditions of shallow groundwater, indicating favorable conditions for growth of microbial population and hence pollution in drinking waters.

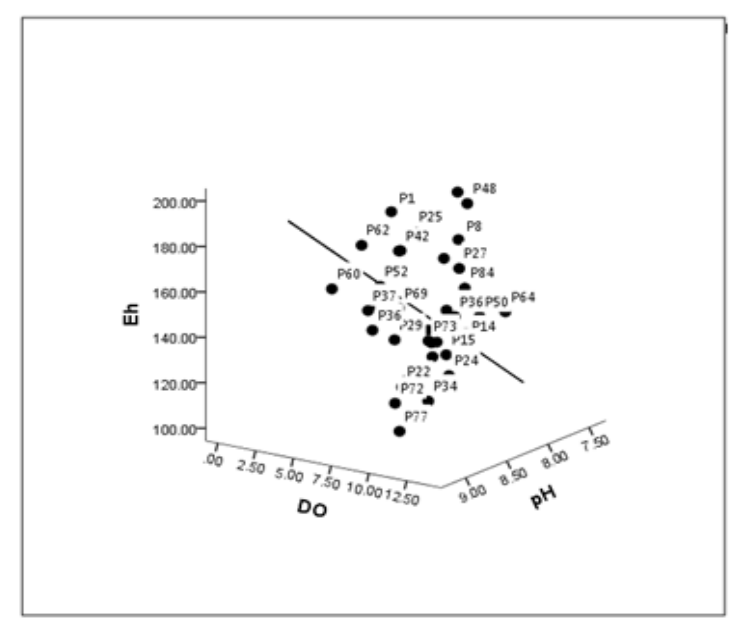

Fig. 2. Relationship between Eh, $p H$ and DO in Pungudutivu groundwater.

A majority of groundwater source localities of Pungudutivu Island exemplify high salinity (95\%) indicating that it cannot be used for drinking, domestic and livelihood purposes as seen in many parts of the Jaffna Peninsula (Saravanan et al., 2013; Pathmaja et al., 2016). The remaining a few freshwater pockets do not indicate any serious contamination risks other than high levels of $\mathrm{Fe}^{2+}$ ranging from 0.44 to $11.79 \mathrm{mg} / \mathrm{L}$ where all groundwater localities exceed the permissible limit of $0.3 \mathrm{mg} / \mathrm{L} \mathrm{Fe}$ of WHO and Sri Lanka standards (Table 1) (WHO 2008, 2017; SLS 2013). $\mathrm{NO}_{3}{ }^{-}$concentrations vary from 0.44 to $30.11 \mathrm{mg} / \mathrm{L}$ in the dry season and 0.44 to $12.4 \mathrm{mg} / \mathrm{L}$ in the wet season and fall below the WHO and SLS guidelines of $50 \mathrm{mg} / \mathrm{L}$ in all wells for 
Table 1. Maximum, minimum and median concentrations of well head parameters and selected ions in Pungudutivu Groundwaters.

\begin{tabular}{|c|c|c|c|c|c|c|}
\hline \multirow[t]{2}{*}{ Parameter } & \multirow[t]{2}{*}{ Season } & \multicolumn{2}{|c|}{$\begin{array}{c}\text { Maximum } \\
\text { permeable limit }\end{array}$} & \multirow[t]{2}{*}{ Minimum } & \multirow[t]{2}{*}{ Maximum } & \multirow[t]{2}{*}{ Median } \\
\hline & & WHO & SLS & & & \\
\hline \multirow[t]{2}{*}{ Temperature $\left({ }^{\circ} \mathrm{C}\right)$} & Dry & $\bullet$ & $\bullet$ & 27.2 & 34.5 & 30.1 \\
\hline & Wet & & & 25.5 & 33.2 & 29.0 \\
\hline \multirow[t]{2}{*}{$\mathrm{pH}$} & Dry & $*$ & $6.5-8.5$ & 6.31 & 9.04 & 8.07 \\
\hline & Wet & & & 6.73 & 9.34 & 7.90 \\
\hline \multirow[t]{2}{*}{$\mathrm{EC}(\mu \mathrm{S} / \mathrm{cm})$} & Dry & $\bullet$ & 750 & 1,071 & $2,02,300$ & 6,540 \\
\hline & Wet & & & 374 & 28,200 & 2,765 \\
\hline \multirow[t]{2}{*}{ DO (mg/L) } & Dry & $\bullet$ & $\bullet$ & 0.19 & 18.50 & 7.16 \\
\hline & Wet & & & 0.30 & 21.19 & 7.84 \\
\hline \multirow[t]{2}{*}{$\mathrm{Fe}^{2+}(\mathrm{mg} / \mathrm{L})$} & Dry & 0.3 & 0.3 & 1.42 & 11.79 & 5.08 \\
\hline & Wet & & & 0.44 & 8.15 & 1.55 \\
\hline \multirow{2}{*}{$\mathrm{NO}_{3}^{-}(\mathrm{mg} / \mathrm{L})$} & Dry & 50 & 50 & 0.44 & 30.11 & 0.89 \\
\hline & Wet & & & 0.44 & 12.40 & 0.44 \\
\hline \multirow[t]{2}{*}{$\mathrm{PO}_{4}{ }^{3-}(\mathrm{mg} / \mathrm{L})$} & Dry & 2.0 & 2.0 & 0.3 & 5.7 & 1.0 \\
\hline & Wet & & & 0.1 & 2.8 & 0.3 \\
\hline
\end{tabular}

*Not of health concern at levels found in drinking-water

- No guideline value for drinking-water is proposed

both seasons. $\mathrm{PO}_{4}{ }^{3-}$ varies from 0.3 to $5.7 \mathrm{mg} / \mathrm{L}$ in the dry season and 0.1 to $2.8 \mathrm{mg} / \mathrm{L}$ in the wet season and $\mathrm{PO}_{4}{ }^{3-}$ concentrations were above the WHO guidelines of $2 \mathrm{mg} / \mathrm{L}$ in $14 \%$ of the wells in the dry season and $3 \%$ in the wet season.

Low concentrations of nutrients in Pungudutivu groundwater are probably due to the scarcely distributed human population and very limited or no agricultural livelihood potentials in the island. Total and faecal coliform counts in groundwater in the Pungudutivu Island imply pollution due to microbial contamination because most of the wells contain greater than 10 total coliforms and faecal coliforms, with a maximum of 180 per $100 \mathrm{ml}$ water samples.

In the Pungudutivu Island, 97\% of the wells fall under the WHO guidelines for BOD (5 $\mathrm{mg} / \mathrm{L}$ ) in both seasons whereas COD levels of groundwater exceed the permissible levels of WHO $(10 \mathrm{mg} / \mathrm{L})$ in $97 \%$ of well waters in the dry season and $61 \%$ in the wet season.
BOD is a useful measure to study the pollution by organic sources both natural and anthropogenic and $\mathrm{BOD}$ with $\mathrm{DO}, \mathrm{NO}_{3}{ }^{-}$and $\mathrm{PO}_{4}{ }^{3-}$ can be a good measure to study the extent of groundwater pollution by decaying organic matter (Revelle, 1988). In Pungudutivu, low nitrate and phosphate concentrations with high COD and low BOD thus demonstrate less pollution by biodegradable organic sources, though there are high oxidising potentials in the shallow dug wells as implied by the stability field of Eh-pH of Pungudutivu groundwater. All groundwater localities of the study area fit well within the $\mathrm{Fe}(\mathrm{OH})_{3}$ stability field on the Eh-pH diagram (Fig 3) and indicate simultaneous consumption of $\mathrm{H}^{+}$and dissolved oxygen for possible oxidation of $\mathrm{Fe}^{2+}$ to the less soluble $\mathrm{Fe}^{3+}$ which in turn is precipitated as ferric hydroxide; and thus can be expressed by the following reaction (Hem and Cropper, 1959).

$$
1 / 2 \mathrm{O}_{2}+2 \mathrm{Fe}^{2+}+2 \mathrm{H}^{+} \longrightarrow 2 \mathrm{Fe}^{3+}+\mathrm{H}_{2} \mathrm{O}
$$


The above condition is reconfirmed by the Eh, $\mathrm{pH}$, and DO plot of groundwater in the study area (Fig. 2), with a weak positive correlation between $\mathrm{DO}$ and $\mathrm{pH}\left(\mathrm{r}^{2}=0.51\right)$. The said trend indicates simultaneous consumption of both free oxygen and hydrogen ions that results in the lowering of Eh and DO while raising the $\mathrm{pH}$ indicated by a negative $R^{2}$ value of -0.52 for DO and Eh. This may be considered for the occurrence of the oxidation of a metal (probably $\mathrm{Fe}^{2+}$ ). However, the argument of high $\mathrm{Fe}^{2+}$ in Pungudutivu groundwater cannot be justified by the said oxidation potential because iron oxides that may occur in the yellow and brown sand formations (ferruginous sand) of Pungudutivu can only dissolve under reducing conditions. At the same time, oxidation of organic matter in the lagoonal and estuarine deposits of the study area is not possible under the prevailing high $\mathrm{pH}$ levels of Pungudutivu groundwater.

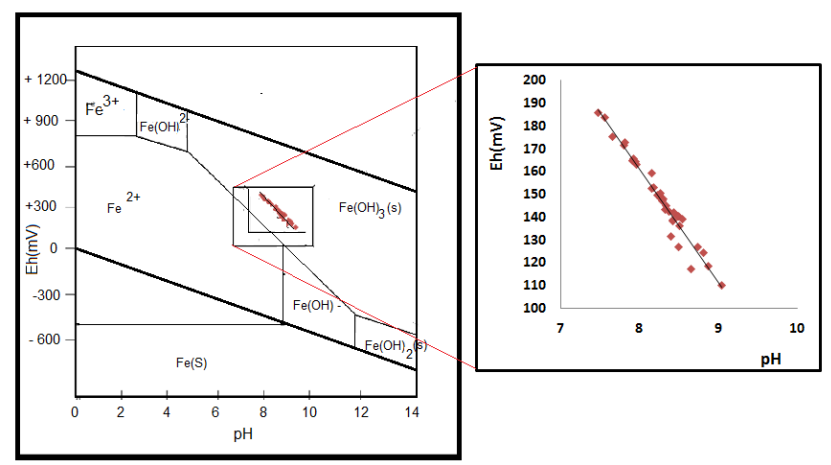

Fig. 3. Eh and $p H$ of Pungudutivu groundwater in the stability field of $\mathrm{Fe}(\mathrm{OH})_{3}$.

High Faecal coliform counts in Pungudutivu groundwater can be mainly due to the shallow depths of unconfined aquifers with high DO and be aggravated due to conditions implied by large numbers of livestock, ways of usage of open dug wells by the local communities, easy infiltration and runoff returns. Groundwater is highly vulnerable against pollution with faecal coliforms in many parts of the island. Owing to these conditions and simple protective methods can be adopted for the prevention of microbial pollution.

\section{CONCLUSIONS}

Pungudutivu is with limited fresh groundwater pockets due to salinisation of groundwaters and the limited fresh groundwater pockets do not indicate any serious contamination risks other than high $\mathrm{Fe}^{2+}$ and high faecal coliform counts. Pungudutivu groundwaters are with low nitrate and phosphate concentrations but with high COD and low BOD and hence demonstrate less pollution from biodegradable organic sources in the midst of high oxidising potentials in the shallow open dug wells as implied by the stability field of $\mathrm{Fe}(\mathrm{OH})_{3}$ on the Eh-pH diagram. However, the argument of high $\mathrm{Fe}^{2+}$ in groundwater cannot be supported by the said oxidation potential. High faecal coliform counts in the shallow depths of groundwater with high DO prevailed may probably be due to conditions implied by on site livestock waste disposal,ways of usage of open dug wells and easy infiltration and runoff returns.

\section{ACKNOWLEDGMENT}

The authors are thankful to the National Research Council (NRC) of Sri Lanka for funding assistance through the grant No. 13-134.

\section{REFERENCES}

Chapman, D. (1996) Water Quality Assessments. A Guide to the Use of Biota, Sediments and Water in Environmental Monitoring. 2nd edition. Chapman \& Hall, London.

Cooray, P.G. (1984) An introduction to the Geology of Sri Lanka (Ceylon). 2nd revised ed. National Museums Sri Lanka, Colombo, pp 126-269.

Hem, J.D. and Cropper, W.H. (1962) Chemistry of Iron in Natural Water- Survey of ferrous-ferric chemical equilibria and redox potentials. United States Government printing office, Washington, Geological Survey Water Supply.

Hidayathulla, M.S.M. and Karunaratna, G.R.R. (2013) Assessment of groundwater quality in shallow aquifers in Jaffna Peninsula. Proceedings of $29^{\text {th }}$ Technical Sessions of Geological Society 
of Sri Lanka, pp 109-113. (http://www.gsslweb.org).

Jeevaratnam, V., Balakumar, S., Mikunthan, T. and Prabaharan, M. (2018) Quality of groundwater in Valikamam area, Jaffna Peninsula, Sri Lanka. International Journal of Water Resources and Environmental Engineering, 10(2): 9-16.

Joshua,W.D., Thushyanthy,M. and Nanthagoban, N. (2013). Seasonal variation of water table and groundwater quality of the karst aquifer of the Jaffna Peninsula, Sri Lanka. National Science Foundation of Sri Lanka, 41(1): 3-12.

Lutterodt, G., Jack van de Vossenberg, Yvonne Hoiting, Alimamy K. Kamara, Sampson OduroKwarteng and Jan Willem A. Foppen. (2018) Microbial groundwater quality status of hand-dug wells and boreholes in the Dodowa Area of Ghana. International Journal of Environmental Research and Public Health, 15(4): 730; https://doi.org/10.3390/ijerph15040730.

Mahagamage, M.G.Y.L., Manage, P.S., and Manage, P.M. (2019) Water quality and microbial contamination status of groundwater in Jaffna Peninsula, Sri Lanka. Journal of Water and Land Development, 40: 3-12.

MENR, UNEP 2009. Sri Lanka Environment Outlook 2009. Ministry of Environment and Natural Resourcesand United Nations Environment Programme, Battaramulla, 154 pp.

Mikunthan, T. and Shanthi De Silva, C. (2008) Vulnerability assessment for shallow aquifers using chemical quality of groundwater: A case study from Thirunelvely and Kondavil in Jaffna District. Journal of Tropical Agricultural Research, 20: 303-312.

Saleem, M., Hussain, A., Mahmood, G. and Waseem, M. (2018) Hydrogeochemical assessment of groundwater in shallow aquifer of greater Noida region, Uttar Pradesh (U.P), India. Applied Water Science, 8:186.

Nesiah, D., Rajasooriyar, L.D. and Jayasingam, T. (2005) The profits of the doom: Agriculture, Construction, Water and Land use in Jaffna peninsula. Proceedings of the $10^{\text {th }}$ International Conference on Sri Lankan Studies, University of Kelaniya, 7pp.

Pathmaja, S. (2016) Geochemistry and the availability of fresh groundwater resources in the Pungudutivu Island, Jaffna, Sri Lanka. Unpublished M.Phil thesis, Faculty of Graduate Studies, University of Jaffna.
Pathmaja, S., Rajasooriyar, L.D., Dharmagunawardhane, H.A., Senthilnanthanan, M. and Mikunthan, T. (2016) Assessment of spatial and temporal behaviour of saline groundwater in a coastal aquifer: A case study from the Pungudutivu Isand, Sri Lanka. Symposium Proceedings of the Water Professionals Day, pp119-130.

Rajasooriyar, L. D., Mathavan, V., Dharmagunewardene, H.A. and Nandakumar, V. (2002) Groundwater quality in the Valigamam region of the Jaffna Peninsula, Sri Lanka. In Sustainable groundwater development, Hiscock, K.M., Rivett, M.O. and Davison, R.M. (eds) Geological Society, London, 193:181-197.

Rajendran, B., Sritharan, K., Vasantharuba, S., Balakumar, S. and Arasaratnam, V. (2008) Evaluation of the microbial and coliform contamination during dry and rainy seasons in water samples collected from some selected schools, Proceedings of the $15^{\text {th }}$ Annual Sessions of the Jaffna Science Association, 14: 51.

Revelle, C. (1988). A sitting model for regional wastewater treatment systems-the chain configuration case. Water Resources Research, 24.

Saravanan, S., Thushyanthy, M., Gunawartana, D. and Gunalan, K. (2013) Spatial Distribution of groundwater salinity at costal region in Jaffna Peninsula: A case study at Karainagar. Conference proceedings of Water Convention 2013, 99-103.

Shivasorupy, B., Lloyd, B.J. and Maier, M. (2012) Sanitary hazards and microbial quality of open dug wells in the Maldives Islands. Journal of Water Resource and Protection, 4: 474-486.

Sri Lanka Standard (SLS) 614:2013 Specification for portable water (First revision). Sri Lanka Standards Institution, Sri Lanka.

World Health Organization (WHO) Guidelines for drinking water quality. (2008) Guidelines for drinking-water quality, $3^{\text {rd }}$ edition incorporating $1^{\text {st }}$ and $2^{\text {nd }}$ addenda, Geneva.

World Health Organization (WHO) Guidelines for drinking- water quality. (2017) Guidelines for drinking-water quality, Fourth edition incorporating first addendum, Geneva. 